\title{
How do Slovak Women Perceive Their Opportunities on the Global Labor Market? Generational study
}

\author{
Mária Urbánová ${ }^{1}$, Jana Kozáková2,*, and Silvia Klátiková ${ }^{3}$ \\ ${ }^{1}$ Slovak University of Agriculture in Nitra, Faculty of Economics and Management, Department of \\ Economics, Trieda A. Hlinku 2, 94976 Nitra, Slovakia \\ ${ }^{2}$ Slovak University of Agriculture in Nitra, Faculty of Economics and Management, Department of \\ Management, Trieda A. Hlinku 2, 94976 Nitra, Slovakia \\ ${ }^{3}$ Bosniacka 67, 91705 Trnava, Slovakia
}

\begin{abstract}
.
Research background: Despite European labor market offers wider opportunities of employment also for Slovak women, it is characterized by notable gender disparities too. Except for the 12\% employment gap, the 16\% wage gap still occurs. Study examines generational differences in attitudes of Slovak woman according to their opportunities on the global labor market with the respect of fact that, women's own views on the need for such activities differ across generations.

Purpose of the article: The aim is to point out that views of Slovak women on their opportunities at the global labor market is perceived differently by women of diverse generations.

Methods: The research was conducted using the questionnaire method on a sample of 361 respondents, who were exclusively women of economically active age already incorporated in the labor market. For this reason, stratified randomization was performed and members of Generations $X$, Generation $\mathrm{Y}$, and Generation $\mathrm{Z}$ were approached to participate in the online survey. The assumptions of differences were set for 6 chosen variables and statistically tested according to the age through Kruskal-Wallis test using XL stat. As a post hoc test the Bonferroni correction was computed to counteract the problem of multiple comparisons between variables.

Findings \& Value added: The uniqueness of our study is primarily in targeting at women of different generations and looking for differences in their generational attitudes.
\end{abstract}

Keywords: woman; generations; global labor market; opportunities; attitudes

JEL Classification: $J 16 ; J 71 ; Z 13$

\footnotetext{
* Corresponding author: jana.kozakova@uniag.sk
} 


\section{Introduction}

Establishing on the labor market is crucial for the professional life of individuals. Finding a suitable job position corresponding to the applicant's education / abilities and the possibility of reconciling work and family life, which is often difficult to solve especially for women. The article focuses on finding out the views of Slovak women on their opportunities in the global labor market. Due to substantial differences in the perceptions of women of different ages, we decided to process it as a generational study.

The labor market can be considered as the set of transactions where the ability to do work is bought and sold. Labor markets vary between developed and developing countries, and by gender and other scopes. One of the ambiguities of the labor market is that it is often arranged to operate with a good or commodity, when in fact it is the ability to do work embedded in people and this social nature gives it special characteristics [1]. Tzannatos [2] in his paper concludes that growth benefits women at large, inequalities can have significantly adverse effects on welfare, and market-based development alone can be a weak instrument for reducing inequality between the sexes. Slovak labor market in 2018 was impacted by employment growth of industrial sector; the number of workers in construction, finance, insurance, administration and healthcare also went up [3]. In 2019, there were $45,71 \%$ of woman out of 2,754,400 economically active inhabitants in Slovakia, with the share of unemployment $6 \%$, even though in case of man it was $4 \%$. Also, the average share of those looking for work in the total number of economically active inhabitants was $4,92 \%$, but, in case of woman it was 5,90 [4]. Based on age distribution, the overall employment grew in almost all age categories, with the highest increase in the group of 35-49 years. Employment decreased in the 15-24 and 55-59 age groups. Also overall short-term migration to work abroad slightly decreased and the enforcement of Slovaks in the global labor market still struggles. Slovak citizens are working mostly in EU countries (Czech Republic and Austria). The greatest number of economic migrants (almost 60,000 people) came from regions of eastern Slovakia [3]. Despite European labor market offers wider opportunities of employment also for Slovak women, it is characterized by notable gender disparities too. Women still remain underrepresented since $67 \%$ of them are currently employed (men's employment is $79 \%$ ). Except this $12 \%$ gap, the $16 \%$ wage gap still occurs. In addition, the burden of private and care responsibilities and the unpaid work, still rests largely on their backs since increase in woman's working hours doesn't automatically lead to more balanced sharing of domestic and caregiving work between genders [5].

Gender order describes the institutional and informal social arrangements that define the complex and changing patterns of gender relations in a particular context [6]. It emphasizes assumes that the man is the primary breadwinner in the family, and the wife is regarded as either a home-based non-market career or a secondary earner [7]. In Slovakia and border countries, where Slovak women most often work, the position of women is still traditional with insufficient pressure on gender order. There is a need of open discussion of analyzing and challenging patterns between the spouses as equal and dynamic, where woman feels positive outcomes for career, family life and gender equality [8].

Although the position of women in society and in the labor market is changing, these changes are slow and visible only for longer time periods, displayable firstly on the generational level. Generally, the most widespread attitude to the stratification of generations is $\mathrm{XYZ}$ approach which recognizes three major generations [9]. Generation $\mathrm{X}$ includes people born between 1965 and 1979. In general, they are motivated at work by the vision of development and career advancement and they consider the success of the company to be the highest value [10]. When choosing a profession, they are most influenced by professionals, but opinions according their careers are influenced by family and friends [11]. Generation Y includes people born between 1980 and 1994, at work they profess personal ownership and 
the motivating element for them is work diversity or creativity. They create an opinion on their career through perception and experience [10]. Generation Z includes people born between 1995 and 2009. They are very technologically advanced and good team players who like to work in groups. They uphold human rights within the moral code [12].

The problem of women's employment in the labor market as well as the perception of obstacles in it has already been investigated by several foreign $[13,14,15]$ and Slovak $[16,17]$ studies. However, the uniqueness of our study is primarily in targeting at women of different generations and looking for differences in their generational attitudes.

\section{Methodology}

The research was conducted using the Google docs. online questionnaire method on a sample of 361 respondents, who were exclusively women of economically active age already incorporated in the labor market. For this reason, stratified randomization was performed and members of Generations X, Y and Z were approached to participate in the online survey. For selection of participants into groups according to generations the design of Mccrindle [9] was used. According this, we identified three generations of included woman: Generation X included participants born from 1965 to 1979, Generation Y included participants born from 1980 to 1994 and Generation $\mathrm{Z}$ included participants born in 1995 and later. The study based on the fact, that [18] these cohorts share the same attitudes, ideas, values and beliefs based on their birth during the same time period and living through common experiences, with macro-level social, political and economic events that occurred during their coming-of-age years. In addition, the passage of these experiences and events reflected their core values concerning jobs, money, tolerance, beliefs, expectations and behaviors remain constant throughout a generation's lifetime and create generational identity.

Population size is represented by 950000 economically active women throughout the chosen generations [19]. With $95 \%$ of probability that the sample truthfully reflects the attitudes of the population and $5 \%$ margin of error, sample of 361 can be considered as representative. Chosen variables for further testing were selected from the questionnaire table 1.

Table 1. Design of questionnaire

\begin{tabular}{|l|l|l|}
\hline No. & Question & Options \\
\hline Q0 & Interval of the year of birth & $\begin{array}{l}1-(1965-1979), 2 \text { - (1980 - 1994), 3. } \\
-(1995 \text { and after) }\end{array}$ \\
\hline Q1 & Highest level of education attained & $\begin{array}{l}1-\text { primarily, 2 - secondary, 3 - first } \\
\text { university degree, 4- second university } \\
\text { degree, 5- third university degree }\end{array}$ \\
\hline Q2 & Form of employment in the global labor market & $\begin{array}{l}\text { 1- student, 2- ordinary employee, 3- } \\
\text { maternity leave, 4-sole trader, 5- } \\
\text { unemployed, 6- middle management, 7- } \\
\text { top management, 8- disability pension }\end{array}$ \\
\hline Q3 & $\begin{array}{l}\text { Do you agree with the statement that women have } \\
\text { less opportunities to become established in the } \\
\text { global labor market (they are disadvantaged) } \\
\text { compared to men? }\end{array}$ & $\begin{array}{l}\text { 1- I strongly agree 2- I rather agree 3- I } \\
\text { don't know 4- I rather disagree 5- I } \\
\text { strongly disagree }\end{array}$ \\
\hline Q4 & $\begin{array}{l}\text { Do you know about the possibilities of education } \\
\text { and acquisition of knowledge (some courses) that } \\
\text { can help you, as a woman, to increase your } \\
\text { chances of finding a job in the global labor } \\
\text { market? }\end{array}$ & $\begin{array}{l}\text { 1-Yes, 2- Rather yes, 3-I can't judge, 4- } \\
\text { Rather not, 5-No }\end{array}$ \\
\hline
\end{tabular}




\begin{tabular}{|l|l|l|}
\hline Q5 & $\begin{array}{l}\text { Have you ever taken the opportunity to up } \\
\text { educate yourself (courses) that helps to increase } \\
\text { opportunities in the global labor market? }\end{array}$ & 1- Yes, 2 - No \\
\hline Q6 & $\begin{array}{l}\text { Do you agree with the statement that women need } \\
\text { to accomplish some up education and courses in } \\
\text { order to increase their chances in the global labor } \\
\text { market? }\end{array}$ & $\begin{array}{l}\text { 1- I strongly agree 2- I rather agree 3- I } \\
\text { don't know 4- I rather disagree 5- I } \\
\text { strongly disagree }\end{array}$ \\
\hline
\end{tabular}

Source: own design

The assumptions of differences for these variables (k- number of samples (groups)) and hypotheses were set:

- $\mathrm{H}_{0}$ : All k populations have the same distribution.

- Ha: Not all k populations have the same distribution.

Alternative hypothesis were formulated in the line with the assumption, that the distribution of variables is different across categories of generations $\mathrm{X}, \mathrm{Y}$ and $\mathrm{Z}$. This assumption based on the theory of generation cohorts [20] which postulates that value orientations are shaped by significant social, political and economic events that occurred during the impressionable pre-adult years, which results in a generational identity and associated set of values, beliefs and expectations that remain relatively stable over a lifetime.

According to above mentioned, the set of $\mathrm{H}_{\mathrm{a}}$ 's were set in a following manner:

$\mathrm{H}_{1}$ : The distribution of education level is different across categories of generation.

$\mathrm{H}_{2:}$ : The distribution of economic activity is different across categories of generation.

$\mathrm{H}_{3}$ : The distribution of opportunities of woman on global labor market is different across categories of generation.

$\mathrm{H}_{4}$ : The distribution of possibilities to educate is different across categories of generation.

$\mathrm{H}_{5}$ : The distribution of participation in courses is different across categories of generation.

$\mathrm{H}_{6:}$ The distribution of the need of the various retraining courses is different across categories of generation.

These hypotheses were statistically tested through the Kruskal-Wallis test using a statistical addition to excel - XL stat. According to p-value lower than the significance level alpha $=0.05$, the null hypothesis $\mathrm{H}_{0}$ can be rejected, and the alternative hypothesis $\mathrm{Ha}$ is accepted. As a post hoc test to the Kruskal-Wallis test the Bonferroni correction test was computed to counteract the problem of multiple comparisons between the examined variables. Bonferroni correction that lowers the critical $P$ values for each particular test based on the number of tests to be performed is frequently used to reduce problems associated with multiple comparisons [21].

Application of generational approach has a few limitations which have to be took into consideration. Youngest generation of respondents ( $Z$ generation) includes individuals who (regarding their age) don't graduate just yet which may have influenced the educational structure of the sample examined. Representation of respondents without university education and with a first university degree may therefore be distorted by the fact that due to age their education could not yet have been completed, which subsequently affected the educational characteristics and secondary an economic activity of the generation $\mathrm{Z}$.

Furthermore, study aimed at the employment as a form of entering labor market and it does not deal with self-employment, even though we won't question the successes, nor the necessity of women entrepreneurs who are running their own businesses. However, the scope of this paper did not allow us to address this phenomenon in the global work environment. In addition, the inclusion of women in entrepreneurship would require a different methodological approach, leading to inconsistencies in results. Last but not least, selfemployment neither affects women's fertility decisions nor does it attract mothers on wage 
and salary contracts. It is chosen by non-employed mothers as it may be the only opportunity for them to enter the labor market [22].

\section{Results and discussions}

Most of the women of economically active age from the survey were among the generation Y (born in 1980-1994) with the number of 169 which makes $47 \%$ of all. They are followed by the 162 answers of women from generation Z (born in 1995 and later) with $45 \%$. The oldest generation X (born in 1965-1979) hold only 8\% which makes 30 answers. This lowest number was expected in this oldest generation due to the fact that the survey was made online. Both, generations $\mathrm{X}$ and $\mathrm{Y}$ are characterized by higher rates of Internet adoption, compared to the older generations [18]. Even though generation $\mathrm{X}$ is characterized by technological and media savvy, the skepticism and pragmatism is typical for them too. On the other hand, generation $\mathrm{Y}$ is considered the first high-tech generation, which describes higher representation of generations $\mathrm{Y}$ and $\mathrm{Z}$ in this study.

The Kruskal-Wallis test was chosen to describe the differences according to the generations $\mathrm{Q}_{0}$ among the other variables with the result of no significations in $\mathrm{Q}_{3}$ and $\mathrm{Q}_{5}$, therefore, we accept the null hypothesis $\mathrm{H}_{0}$ and reject the hypothesis $\mathrm{H}_{3}$ and $\mathrm{H}_{5}$.

Table 2. Kruskal-Wallis test $\mathrm{H}_{1}$ : The distribution of education level is different across categories of generation

\begin{tabular}{|l|r|}
\hline K (Observed value) & 98.292 \\
\hline K (Critical value) & 5.991 \\
\hline DF & 2 \\
\hline p-value (Two-tailed) & $<\mathbf{0 , 0 0 0 1}$ \\
\hline alpha & 0.05 \\
\hline
\end{tabular}

Source: own processing

The risk to reject the null hypothesis $\mathrm{H}_{0}$ while it is true is lower than $0.01 \%$. As the computed $p$-value is lower than the significance level alpha $=0.05$, the null hypothesis is rejected and the alternative hypothesis $\mathbf{H}_{1}$ is accepted (table 2). Ties have been detected in the data and the appropriate corrections have been applied using Bonferroni correction:

Table 3. Bonferroni correction H1

\begin{tabular}{|l|r|r|r|}
\hline Questions & Q1 $\mid 2$ & Q1 1 & Q2 $\mid 3$ \\
\hline Q2 2 & 1 & $\mathbf{0 . 0 0 1}$ & $<\mathbf{0 , 0 0 0 1}$ \\
\hline $\mathrm{Q} 2 \mid 1$ & $\mathbf{0 . 0 0 1}$ & 1 & 0.033 \\
\hline $\mathrm{Q} 2 \mid 3$ & $<\mathbf{0 , 0 0 0 1}$ & 0.033 & 1 \\
\hline
\end{tabular}

Bonferroni corrected significance level: 0.0167

Source: own processing

From the table 3 high significant differences between education levels according to generations can be seen in generations 2 and 1 ; and 2 and 3 . This means that the education level of women born in 1980-1994 is significantly different compared to the other two generations and most of these women obtained second university degree, while most of the younger and older women obtained both first university degree. In our opinion, similar outcomes of generation X and Z has different reasons. A part of examined Z's doesn't graduate second university degree just yet, which was described as limitation of this study. On the other hand, university degree in case of X's, especially women is quite unique in 
Slovakia. Almost $20 \%$ of today's 60 -year-olds, do not even have an apprenticeship today and $28 \%$ only have a vocational education with an apprenticeship certificate or a final exam [19]. Among women in their thirties (30-34), the proportion of women with such education is significantly lower. On the other hand, almost $40 \%$ of Slovak woman in their thirties now have a second-level university degree.

Table 4. Kruskal-Wallis test $\mathrm{H}_{2}$ : The distribution of economic activity is different across categories of generation

\begin{tabular}{|l|r|}
\hline K (Observed value) & 125.614 \\
\hline K (Critical value) & 5.991 \\
\hline DF & 2 \\
\hline p-value (Two-tailed) & $<\mathbf{0 , 0 0 0 1}$ \\
\hline alpha & 0.05 \\
\hline
\end{tabular}

Source: own processing

The risk to reject the null hypothesis $\mathrm{H} 0$ while it is true is lower than $0.01 \%$. As the computed $\mathrm{p}$-value is lower than the significance level alpha $=0.05$, the null hypothesis is rejected and the alternative hypothesis $\mathbf{H}_{2}$ is accepted (table 4). Appropriate corrections have been applied:

Table 5. Bonferroni correction $\mathrm{H} 2$

\begin{tabular}{|r|r|r|r|}
\hline Questions & $\mathrm{Q}_{2} \mid 2$ & $\mathrm{Q}_{2} \mid 1$ & $\mathrm{Q}_{2} \mid 3$ \\
\hline $\mathrm{Q}_{2} \mid 2$ & 1 & 0.672 & $<\mathbf{0 , 0 0 0 1}$ \\
\hline $\mathrm{Q}_{2} \mid 1$ & 0.672 & 1 & $<\mathbf{0 , 0 0 0 1}$ \\
\hline $\mathrm{Q}_{2} \mid 3$ & $<\mathbf{0 , 0 0 0 1}$ & $<\mathbf{0 , 0 0 0 1}$ & 1 \\
\hline
\end{tabular}

Bonferroni corrected significance level: 0.0167

Source: own processing

After post hoc test (table 5) high significant differences in economic activity among generations can be concluded for the generations 3 and 1; 3and 2. The youngest generation born in 1995 and after is significantly different compared to others while most of the women of this generation (107) are still students. This connects to the limitation of the study, while most of them didn't finish their studies yet and the presumption of economic activity for the youngest generation was, that most of them would still be students.

Table 6. Kruskal-Wallis test $\mathrm{H}_{4}$ : The distribution of possibilities to educate is different across categories of generation.

\begin{tabular}{|l|r|}
\hline K (Observed value) & 9.475 \\
\hline K (Critical value) & 5.991 \\
\hline DF & 2 \\
\hline p-value (Two-tailed) & $\mathbf{0 . 0 0 9}$ \\
\hline alpha & 0.05 \\
\hline
\end{tabular}

Source: own processing

The risk to reject the null hypothesis $\mathrm{H}_{0}$ while it is true is lower than $0.88 \%$. As the computed $\mathrm{p}$-value is lower than the significance level alpha $=0.05$, the null hypothesis is rejected and the alternative hypothesis $\mathbf{H}_{4}$ is accepted. Appropriate corrections have been applied: 
Table 7. Bonferroni correction $\mathrm{H} 4$

\begin{tabular}{|l|r|r|r|}
\hline \multicolumn{1}{|c|}{ Questions } & Q4 $\mid 2$ & Q4 $\mid 1$ & Q4 3 \\
\hline Q4 $\mid 2$ & 1 & 0.289 & $\mathbf{0 . 0 1 3}$ \\
\hline Q4 $\mid 1$ & 0.289 & 1 & $\mathbf{0 . 0 1 5}$ \\
\hline Q4 $\mid 3$ & $\mathbf{0 . 0 1 3}$ & $\mathbf{0 . 0 1 5}$ & 1 \\
\hline
\end{tabular}

Note: Bonferroni corrected significance level: 0.0167

Source: own processing

From the Bonferroni correction of $\mathrm{H}_{4}$ (table 7) significant differences in possibilities to educate among generations 1 and 3;2 and 3 were found. Most of the women from all three generations stated that they know about the possibilities of education and acquisition of knowledge that can help them to increase chances of finding a job in the global labor market. Similarly, as in the $\mathrm{H}_{2}$ the youngest generation significantly differs from the others. We believe, that it is not an only explanation, since generation $\mathrm{Z}$ is generally considered different in many ways regarding their close connection to online world, informational technologies and ability to search and use information. Technology, in particular the rapid evolution of how people communicate and interact is generation-shaping consideration. Baby Boomers grew up as television expanded dramatically, changing their lifestyles and connection to the world in fundamental ways. Generation $\mathrm{X}$ grew up as the computer revolution was taking hold, and generation $\mathrm{Y}$ came of age during the internet explosion. What older generations have to adapt to, Generation $\mathrm{Z}$ born into and live in naturally. Therefore, their opinion on the acquisition of particular knowledge can be influenced by their different approach when comparing with older generations [23].

Table 8. Kruskal-Wallis test $\mathrm{H}_{6}$ : The distribution of the need of the various retraining courses is different across categories of generation

\begin{tabular}{|l|r|}
\hline K (Observed value) & 8.017 \\
\hline K (Critical value) & 5.991 \\
\hline DF & 2 \\
\hline p-value (Two-tailed) & $\mathbf{0 . 0 1 8}$ \\
\hline alpha & 0.05 \\
\hline
\end{tabular}

Source: own processing

The risk to reject the null hypothesis $\mathrm{H}_{0}$ while it is true is lower than $1.82 \%$. As the computed p-value is lower than the significance level alpha $=0.05$, the null hypothesis is rejected and the alternative hypothesis $\mathbf{H}_{6}$ is accepted. Ties have been detected in the data and the appropriate corrections have been applied:

Table 9. Bonferroni correction H6

\begin{tabular}{|l|r|r|r|}
\hline \multicolumn{1}{|c|}{ Questions } & $\mathrm{Q}_{6} \mid 2$ & $\mathrm{Q}_{6} \mid 1$ & $\mathrm{Q}_{6} \mid 3$ \\
\hline $\mathrm{Q}_{6} \mid 2$ & 1 & 0.117 & 0.065 \\
\hline $\mathrm{Q}_{6} \mid 1$ & 0.117 & 1 & $\mathbf{0 . 0 1 0}$ \\
\hline $\mathrm{Q}_{6} \mid 3$ & 0.065 & $\mathbf{0 . 0 1 0}$ & 1 \\
\hline
\end{tabular}

Note: Bonferroni corrected significance level: 0.0167

Source: own processing

After the correction the only significant difference in H6 was between the generation 1 and 3. The youngest and the oldest generations differ in the need of the various retraining 
courses. Most of the women from youngest generation (43) rather agree on the need of these courses, while most of the women from oldest generation (14) strongly agree on the need of the courses. Difference in opinion of youngest and eldest generation shows clearly generational discrepancy described by several studies, out of which characterization of Generation Z speaking of all: Generation Z is interested in new technologies, insist on ease of use, desire to feel safe, and temporarily escape the realities it face [24]. People of this generation are young, but have experienced political, social, technological and economic changes. On the other hand, [11] generation $\mathrm{X}$ is the group that started to introduce the idea of a solid work-life balance into the workforce. Even though described differences between generations $\mathrm{X}$ and $\mathrm{Z}$ explains our outcomes, there is still the factor of un experience of generation $\mathrm{Z}$ and there is a possibility that in a long time period, they change their opinion closer to Generation X. Dimock [23] proves dramatic shifts in youth behaviors, attitudes and lifestyles, both positive and concerning and highlighted, that what we don't know is whether these are lasting generational imprints or characteristics of adolescence that will become more muted over the course of their adulthood.

\section{Conclusion}

Study examines generational differences in attitudes of Slovak woman according to their opportunities on the global labor market. Slovak citizen most likely enter foreign labor markets of neighboring countries. Determined gender differences of the labor market are also reflected in the disadvantaged position of women and the need to help them expand the possibilities of their application at global labor market. However, women's own views on the need for such activities differ across generations. According to realized statistical analysis we can outline the significant differences between:

- education of generations X and Y; and Y and Z. The majority of examined woman of Y generation obtained second university degree, while most of the younger and older women obtained both first university degree,

- economic activity among generations $\mathrm{Z}$ and $\mathrm{X} ; \mathrm{Z}$ and $\mathrm{Y}$. The youngest generation significantly differ while most of the women of this generation are still students,

- possibilities to educate among generations X and Z; Y and Z. Most of the women from all three generations stated that they know about the possibilities of education and acquisition of knowledge that can help them to increase chances of finding a job in the global labor market.

- need of the various retraining courses among generation X and Z. Most of the women from youngest generation rather agree on the need of these courses, while most of the women from oldest generation strongly agree on the need of the courses.

The hypotheses H1, H2, H4, and H6 were accepted as a result of the outcome of the Kruskal-Wallis test. Bonferroni correction was then applied to find and describe the ties between the generations. Among the youngest generation born in 1995 and after, significant differences in all the accepted hypotheses were seen. This generation always differs, what makes it an interesting outcome for further research. We believe, that these differences in opinions are connected with the natural singularity of selected generations. Our outcomes indicate, that generation $\mathrm{Z}$ should be brought to the forefront in the same way as Generation $\mathrm{X}$ has been since organizations are still at large not much bothered of them and society is just getting influenced seriously by them [25].

Paper was prepared within the project "Theory and Practice of International Management and Business in Multicultural Environment" no. 005SPU-4/2019 supported by KEGA Agency of the Ministry of Education, Science, Research and Sport of the Slovak Republic 


\section{References}

1. Carmody, P. (2009). Labor Market. International Encyclopedia of Human Geography (pp. 65-70). Elsevier: UK.

2. Tzannatos, Z. (1999). Women and labor market changes in the global economy: Growth helps, inequalities hurt and public policy matters. World development, 27(3), 551-569.

3. EURES, (2020, July 10). Labour market information. Retrieved from: https://ec.europa.eu/eures/main.jsp?catId=2806\&countryId=SK\&acro=lmi\&lang=en\&r egionId $=$ SK0\&nuts 2 Code $=\% 20 \&$ nuts 3 Code $=\&$ regionName $=$ National $\% 20$ Level

4. Eurostat, (2020, July 18). STATdat. Public database. Employment. Retrieved from: http://statdat.statistics.sk/cognosext/cgi-bin/

5. EC. (2020). Women's situation in the labour market. Retrieved from: https://ec.europa.eu/info/policies/justice-and-fundamental-rights/genderequality/women-labour-market-work-life-balance/

6. Connell, R. W. (2013). Gender and power: Society, the person and sexual politics. John Wiley \& Sons.

7. Gherardi, S., Poggio, B. (2001). Creating and recreating gender order in organizations. Journal of World Business, 36(3), 245-259.

8. Heikkinen, S., Lämsä, A. M., Hiillos, M. (2014). Narratives by women managers about spousal support for their careers. Scandinavian Journal of Management, 30(1), 27-39.

9. Stewart, J. S., Oliver, E. G., Cravens, K. S., Oishi, S. (2017). Managing millennials: Embracing generational differences. Business Horizons, 60(1), 45-54.

10. McCrindle, M., Wolfinger, E. (2009). The ABC of XYZ: Understanding the global generations. The ABC of XYZ.

11. McCrindle, M. (2011). An Excerpt FromThe ABC of XYZ: Understanding the global generations beyond z: meet generation alpha. McCrindle Research Pty, Australia.

12. Caraher, L. (2016). Millennials \& management: The essential guide to making it work at work. Routledge.

13. Deniz, N., Deniz, S., Ertosun, Ö.G. (2012). The woman-friendly organization-effects of demographic variables on women employees' perception about their companies on work and family-oriented woman-friendly HRM: A study in banking industry in Turkey. Procedia-Social and Behavioral Sciences, 41, 477-484.

14. Powell, G. N., Butterfield, D. A. (2015). The preference to work for a man or a woman: A matter of sex and gender?. Journal of Vocational Behavior, 86, 28-37.

15. Asi, Y., Williams, C. (2020). A woman's (unpaid) work: Global perspectives on gender, healthcare, and caregiving. In Three Facets of Public Health and Paths to Improvements (pp. 261-294). Academic Press.

16. Kureková, L. (2010). Ludský kapitál: Zamestnanost' a pracovná sila. Správa o stave podnikatel'ského prostredia v SR. Bratislava: Stredoeurópska univerzita Budapeńt' a CELSI.

17. Novakova, L. (2020). The impact of technology development on the future of the labour market in the Slovak Republic. Technology in Society, Art. No. 101256.

18. Lissitsa, S., Kol, O. (2016). Generation X vs. Generation Y-A decade of online shopping. Journal of Retailing and Consumer Services, 31, 304-312.

19. SOSR, (2020, July 28). Demography and social statistics. Public Database STATdat. Statistical Office of the Slovak Republic. Retrieved from: http://statdat.statistics.sk/cognosext/ 
20. Inglehart, R. (2020). Modernization and postmodernization: Cultural, economic, and political change in 43 societies. Princeton university press.

21. Cabin, R. J., Mitchell, R. J. (2000). To Bonferroni or not to Bonferroni: when and how are the questions. Bulletin of the Ecological Society of America, 81(3), 246-248.

22. Matysiak, A., Mynarska, M. (2020). Self-Employment as a Work-and-Family Reconciliation Strategy? Evidence from Poland. Advances in Life Course Research, Art. No. 100329.

23. Dimock, M. (2019). Defining generations: Where Millennials end and Generation Z begins. Pew Research Centre.

24. Priporas, C. V., Stylos, N., Fotiadis, A. K. (2017). Generation Z consumers' expectations of interactions in smart retailing: A future agenda. Computers in Human Behavior, 77, 374-381.

25. Singh, A. (2014). Challenges and issues of generation Z. IOSR Journal of Business and Management, 16(7), 59-63. 